\title{
El archivo de la Fundación Casa de Medina Sidonia: un sueño hecho realidad
}

La Fundación Casa de Medina Sidonia es una institución creada en el año 1990 por doña Luisa Isabel Álvarez de Toledo, XXI Duquesa de Medina Sidonia. Ya con anterioridad el Palacio, con todo cuanto contiene, fue declarado Monumento Histórico Artístico Nacional. Su objetivo principal es la conservación y difusión de los bienes que lo integran: el archivo histórico de los Duques de Medina Sidonia, compuesto por más de seis millones de documentos; el Palacio de Sanlúcar de Barrameda, que data del siglo XII, y su patrimonio pictórico y mobiliario. En este principio de valorización del patrimonio cultural, la Fundación organiza conferencias, seminarios, exposiciones, cursos de verano -durante varios años acogió a la Universidad Nacional de Educación a Distancia en sus instalaciones-, conciertos, y divulga, a través del estudio de sus fondos documentales, por parte de los investigadores que acuden al archivo, los trabajos de historia que éstos realizan.

Quiso la fundadora, y así queda reflejado en los estatutos fundacionales, que esta institución fuese centro difusor de cultura, debiendo servir al hombre en su búsqueda de la verdad objetiva, que tiene por base el conocimiento del pasado; pues las sociedades, como bien queda señalado en nuestro Ideario, "no pueden asumir lo nuevo, partiendo del vacío".

Podemos afirmar, sin lugar a equivocarnos, que la importancia de este archivo radica en la composición de sus fondos documentales, constituidos por seis millones de documentos, reunidos en 6245 legajos, 0 unidades de instalación, lo que nos permite profundizar desde diversos ángulos: económicos, políticos, filosóficos, sociológicos, juridicos, etcétera, en periodos que nos ofrecen la imagen del mundo tal y como fue, distinguiendo el "gran hecho" del minúsculo, dándonos a conocer los fundamentos inherentes que tienen las acciones de los hombres en la construcción y devenir de las sociedades.

En este archivo se reúne la documentación que distintas familias, o casas, fueron generando a lo largo de los siglos, siendo el bloque documental más grande el de Medina Sidonia, que data de finales del siglo XIII (1297). Está el archivo de los Vélez (Fajardo), el de Requesens (Martorell), Montalto (Aragón y Moncada), Maza de Linaza (Caro y Romana) y el de Villafranca (de Toledo), este último menos completo que el de Medina Sidonia, pero es el que nos ofrece la documentación más antigua, que comienza en el año 1190.

La ordenación por materias es prácticamente la misma para todas las casas, quedando reflejada en los siguientes bloques temáticos, construidos a partir de los catálogos realizados por la fundadora, y que obran en el Archivo, siendo la herramienta principal de trabajo para el investigador a la hora de realizar la búsqueda documental:

\section{Sección Privada:}

a) Nacimientos, matrimonios, testamentos y testamentarías, con un apartado de pleitos que dimanan de ello, como por ejemplo: separaciones y sucesiones. b) Correspondencia de carácter familiar o social. Correspondencia privada, que nos señala fundamentalmente la construcción social y mental de la sociedad del momento.

c) Cuentas particulares, en las que queda reflejado el gasto personal, como pueden ser los salarios de criados, sastres, adquisición de bienes, usos alimenticios, gustos, etcétera. Sueldos de pintores, escultores, armeros, plateros, joyeros, entre otros oficios o profesiones.

d) Deudas, censos, juros y pleitos tocantes a estos temas, que nos hablan a su vez del mundo de la justicia y de las estrategias de poder que construyen las sociedades, describiéndonos la función activa que ejercen las partes en litigio. En la misma sección, pero en apartado distinto nos encontramos las instrucciones a los administradores, tesoreros y secretarios, asi como los mecanismos utilizados por los bancos $y$ banqueros a la hora de adelantar o facilitar el tránsito del dinero que prestan.

e) Rentas jurisdiccionales o señoriales; bienes propios unidos al mayorazgo, bienes libres. Apartado que queda subdividido por la documentación que nos remite a las formas de arriendo de las dehesas, huertas, viñas, casas, molinos, mesones, y demás propiedades de las distintas casas.

f) Encomiendas, que solia dar el rey a las casas que estaban en apuros financieros, así como los ingresos dimanantes de privilegios reales y rentas vitalicias. En este apartado también debemos incluir los ingresos que dimanaban del ejercicio de los distintos cargos que ejercian los nobles; ingresos que nunca llegaron a cubrir los gastos del empleo. Se trata de empleos políticos o militares, como los virreinatos, capitanías generales, etcétera, o los honorificos, como los hábitos de órdenes, condecoraciones y otros, sin carácter lucrativo, o con pensiones mínimas.

g) Patronatos generales de órdenes, provinciales o locales. Fundaciones de conventos o iglesias: bulas, buletos, excomuniones, censura y pleitos eclesiásticos.

h) Obras sociales, documentación que nos remite a la creación o fundación de hospitales, colegios, asilos, limosnas y situados vitalicios.

\section{Sección Estado o Señorío:}

a) Impuestos o tributos con cargo a los pueblos del estado, bien por pertenecer a señorí, o bien por haberlos adquirido por compra, como los llamados alcabalas, terrazgo, almotacén, aduana, etcétera. Ingresos dimanantes del alquiler sobre las tiendas públicas, carniceria, pescaderías, casas de mujeres, hornos y molinos.

b) Privilegios y concesiones a los pueblos en su conjunto, a vecinos en particular, a nuevos pobladores.

c) Órdenes tocantes a cuestiones de gobierno y administración pública. Intervención en demandas contra los justicias y entre los vecinos (Tribunal de Apelación o Consejo).

d) Obras públicas; introducción de industrias, repoblaciones forestales e introducción de plantas y técnicas agrarias.

e) Elecciones de justicias; pleitos con el vecindario, generalmente sobre propiedad de tierras, cobro de impuestos o legítima del señorío jurisdiccional.

f) Pleitos con los vasallos, generalmente por deudas o desacato. A veces contra un grupo, otros contra un particular. Correspondencia con justicias y vecinos.

g) Relación con la corona: privilegios reales, concediendo el señorío. Pleitos de la corona contra las regalias del señor (recuperación de impuestos, tierras y otros, dados por anteriores soberanos).

h) Relaciones entre el rey y los pueblos: privilegios reales, fueros, concesión de dehesas, etcétera. Pleitos de los pueblos contra la corona: recuperación de tierras, en torno a impuestos, que son de la ciudad o lugares. Contra los oficiales de la corona.

j) Relaciones entre los pueblos: privilegios, pleitos de la villa en torno a su jurisdicción. Pleitos con lugares vecinos sobre comunidad de pastos, entradas de ganado, límites, apeos, deslindes. Pleitos entre los vecinos, causas criminales, delitos, acuerdos y desacuerdos del cabildo. Elecciones de justicias, juicios de residencias.

k) Urbanismo y obras públicas; fiestas populares, servicios sociales; médicos, maestros; escribanías y procuradores. Oficios públicos en general. Informes y descripciones geográficas, económicas e históricas de los lugares. Baldios y su administración, dehesas y su administración. Bienes privados.

Esta rica documentación nos permite estudiar y entender el pasado en todos sus aspectos, mostrándonos con su lenguaje propio nuestro devenir como hombres, pues el saber de dónde venimos nos ayuda a comprender lo que hoy somos y representamos. Asi lo han podido comprobar los cientos de investigadores y estudiosos que han pasado por su sala, estudiando sus ricos fondos documentales; dando vida a innumerables trabajos históricos que han enriquecido el panorama científico de nuestro país.

Para finalizar quisiera aprovechar estas páginas para recordar a las instituciones públicas que son los garantes de que este patrimonio se conserve y se difunda, para ello hace falta que colaboren activamente en la consecución de los fines fundacionales, tal y como dispuso doña Luisa Isabel Álvarez de Toledo al constituir la Fundación. En esta nueva andadura, los patronos hemos de ser conscientes de que es necesario dar una mayor difusión a las actividades que se realizan en torno al Archivo, que ha de ser considerado Patrimonio Mundial, por ello es preciso que dispongamos de los recursos necesarios, tanto técnicos como económicos, para llevar a cabo esta ingente tarea que nos fue confiada en toda su complejidad y diversidad, y a la que debemos dar la mayor difusión posible.

Liliane $M^{a}$ Dahlmann

Presidenta de la Fundación Casa de Medina Sidonia 